\title{
Marine Litter
}

\author{
Monia Renzi ${ }^{1, *}$ and Cristiana Guerranti ${ }^{1,2}$
}

1 Department of Life Sciences, University of Trieste, Via L. Giorgieri 10, 34127 Trieste, Italy; cristianaguerranti@alice.it

2 Consorzio Interuniversitario per lo Sviluppo dei Sistemi a Grande Interfase (CSGI), University of Florence, Via della Lastruccia 3, Sesto Fiorentino, 50019 Florence, Italy

* Correspondence: mrenzi@units.it

Citation: Renzi, M.; Guerranti, C. Marine Litter. J. Mar. Sci. Eng. 2021, 9, 608. https://doi.org/10.3390/ jmse9060608

Received: 26 May 2021

Accepted: 27 May 2021

Published: 1 June 2021

Publisher's Note: MDPI stays neutral with regard to jurisdictional claims in published maps and institutional affiliations.

Copyright: (c) 2021 by the authors. Licensee MDPI, Basel, Switzerland. This article is an open access article distributed under the terms and conditions of the Creative Commons Attribution (CC BY) license (https:/ / creativecommons.org/licenses/by/ $4.0 /)$.
This short editorial aims to present the content of, summarize and draw conclusions from the six articles published in the Special Issue "Marine Litter".

Marine litter represents an important threat to marine ecosystems, with plastic debris, its principal component, being found worldwide and levels expected to increase. Midocean gyres are only the tip of the iceberg concerning the plastic pollution problem in aquatic ecosystems. Large floating plastics could impact marine species, but microplastics affect all environmental matrices from remote areas to deep oceans [1-3]. The absorption of chemicals on plastic surfaces and microplastic translocation from the environment towards different levels of the trophic web have been recorded, and humans can be affected by microplastics exposure through seafood [4]. In recent decades, scientific knowledge has been significantly improved, but there remain big questions that are yet unanswered regarding microplastics research fields. This Special Issue aimed to fill some existing knowledge gaps, encouraging the submission of original research and reviews focusing on:

- sources;

- transport routes;

- distribution pathways;

- comparative analyses among plastic types;

- ecotoxicological responses;

- impacts on organisms and human health;

- main methodological problems.

The main sources of plastic pollution in marine systems are considered to be plastic debris occurring in freshwater environments, either coming from the surrounding terrestrial areas or transported from upstream. The ocean is the final destination of land-based microplastic sources, but compared to marine environments, the occurrence and effects of microplastics in freshwater ecosystems remain largely unknown. This is what emerged from a thorough examination of the scientific literature on the abundance, distribution patterns, and characteristics of microplastics in freshwater environments in Mediterranean tributary rivers, with a substantial lack of information and the need to apply adequate and uniform measurement methods [5].

A survey of marine coastal litter around Zhoushan Island (China) reported an original contribution to the knowledge of marine litter diffusion, applying a stratified random sampling (StRS) method and a univariate analysis of variance to assess the amount of litter in different landforms that include mudflats, artificial and rocky beaches, and designing two questionnaires for local fishermen and tourists to provide social scenarios. The results showed that the distribution of litter in different landforms was significantly different, while the distribution of litter in different sampling points had no significant difference. Based on the social-ecological scenarios that emerged, governance recommendations were provided by the authors [6]. Social aspects are also considered in another research paper of this Special Issue, which addresses the issue of marine litter in African small island developing states [7]. The study intended to explore the perceptions of local island 
fishing communities in Cape Verde regarding marine litter, in order to contribute to an improvement of marine ecosystem management and development of conservation policies. To achieve that, two participatory sessions were conducted in two communities on the island of Santiago. The results showed that the population were very aware of the marine litter problem, being able to identify the lack of a proper waste management system on the island and the inappropriate behaviors of the population as the main causes of this problem. Equipment damage and the presence of plastic inside fish were the most relevant impacts identified by the participants. These findings reinforce previous research on the importance of public engagement and environmental education to contribute to the conservation of marine ecosystems and to build a strong collaborative ocean governance.

A further contribution to the knowledge of the diffusion of marine litter and a focus on the dynamics of diffusion and transport was provided by a research article that combined modeling and field data on floating litter on the Algarve coast [8]. The results showed a considerable concentration of marine litter along the beaches and coastal regions; the model also suggested that oceanographic conditions and wind drift have a great influence on the transport and accumulation rate of the floating marine litter on the coast.

Regarding the effects that the plastics component of marine litter has on organisms, a research study evaluated the impacts of different leachates of plastic-made packaging on marine species of different trophic levels [9]. Standard ecotoxicological endpoints and alterations of ecologically significant parameters were measured following exposure under different $\mathrm{pH}$ water conditions: the marine standard and two increasingly acidic conditions, in order to evaluate possible variations induced by ocean acidification as a consequence of global change. The results obtained evidenced that the tested doses were not able to significantly affect bacteria and algae, while larvae of Paracentrotus lividus were significantly affected by several packaging types (13 out of 16) with meaningless differences between $\mathrm{pH}$ conditions.

Finally, an original study reports the results of monitoring regarding the burden of marine litter on human health [10]. Eleven commercial trademarks of table salt of marine origin coming from Italy and Croatia were analyzed. Levels and the chemical composition of microparticles measured in commercial products were correlated on a statistical basis to some factors of variability of potential scientific interest (geographical origin of marine salt, cost of commercial product, etc.). The results of the analyses performed on the tested size fraction $(<150 \mu \mathrm{m})$ of microparticles evidence pollution by litter and, in particular, levels of microplastics are within 0.17-0.32 items/g (Italy) and 0.07-0.20 items/g (Croatia). The different nations also showed a different chemical composition of microplastics recovered from analyzed trademarks (PET and PVC from Italy; PA, PP, and nylon from Croatia). The results allowed the authors to assess the annual amount ingested by humans from marine salt consumption in ranges of 131.4-372.3 items/y (Croatia) and 306.6-580.35 items/y (Italy). Further studies are needed to better explore on statistical a basis, if both the levels and chemical composition of MPs in table salt of marine origin can be used as good indicators of marine pollution.

The contributions published in this Special Issue provide important general and local information on the diffusion and impact of marine litter, considered from different perspectives. What appears clear is that, in the face of the multiplication of monitoring studies, ecotoxicological tests, and forecasting models, further steps forward will have to be made in the global knowledge and understanding of the phenomenon, even in aspects that have probably not yet fully emerged. The involvement of world populations will be crucial; people worldwide will have to be sensitized and educated on how to counteract the damage caused by the litter already present at sea and how to prevent the problem from worsening. At higher levels, governments, national and supranational, will have to manage with priority the issue of severe rules to mitigate the pollution already in place and absolutely prevent it from worsening in the future. The implementation of a global model of sustainable development will also pass through these management aspects. 
Funding: This research received no external funding.

Institutional Review Board Statement: Not applicable.

Informed Consent Statement: Not applicable.

Data Availability Statement: No new data were created or analyzed in this study.

Conflicts of Interest: The authors declare no conflict of interest.

\section{References}

1. Martellini, T.; Guerranti, C.; Scopetani, C.; Ugolini, A.; Chelazzi, D.; Cincinelli, A. A snapshot of microplastics in the coastal areas of the Mediterranean Sea. Trends Anal. Chem. 2018, 109, 173-179. [CrossRef]

2. Renzi, M.; Blaskovic, A.; Fastelli, P.; Marcelli, M.; Guerranti, C.; Cannas, S.; Barone, L.; Massara, F. Is the microplastic selective according to the habitat? Records in amphioxus sands, Maerl bed habitats and Cymodocea nodosa habitats. Mar. Pollut. Bull. 2018, 130, 179-183. [CrossRef] [PubMed]

3. Pastorino, P.; Pizzul, E.; Bertoli, M.; Anselmi, S.; Kušće, M.; Menconi, V.; Prearo, M.; Renzi, M. First insight into plastic and microplastic occurrence in biotic and abiotic compartments, and snow from high-mountain lake (Carnic Alps). Chemosphere 2021, 265, 129121. [CrossRef] [PubMed]

4. Renzi, M.; Guerranti, C.; Blaškovic, A. Microplastic contents from maricultured and natural mussels. Mar. Pollut. Bull. 2018, 131, 248-251. [CrossRef]

5. Guerranti, C.; Perra, G.; Martellini, T.; Giari, L.; Cincinelli, A. Knowledge about Microplastic in Mediterranean Tributary River Ecosystems: Lack of Data and Research Needs on Such a Crucial Marine Pollution Source. J. Mar. Sci. Eng. 2020, 8, 216. [CrossRef]

6. Ma, X.; Zhou, Y.; Yang, L.; Tong, J. A Survey of Marine Coastal Litters around Zhoushan Island, China and Their Impacts. J. Mar. Sci. Eng. 2021, 9, 183. [CrossRef]

7. Ferreira, J.C.; Monteiro, R.; Vasconcelos, L.; Duarte, C.M.; Ferreira, F.; Santos, E. Perception of Citizens Regarding Marine Litter Impacts: Collaborative Methodologies in Island Fishing Communities of Cape Verde. J. Mar. Sci. Eng. 2021, 9, 306. [CrossRef]

8. Rosas, E.; Martins, F.; Janeiro, J. Marine Litter on the Coast of the Algarve: Main Sources and Distribution Using a Modeling Approach. J. Mar. Sci. Eng. 2021, 9, 412. [CrossRef]

9. Piccardo, M.; Provenza, F.; Grazioli, E.; Anselmi, S.; Terlizzi, A.; Renzi, M. Impacts of Plastic-Made Packaging on Marine Key Species: Effects Following Water Acidification and Ecological Implications. J. Mar. Sci. Eng. 2021, 9, 432. [CrossRef]

10. Renzi, M.; Grazioli, E.; Bertacchini, E.; Blašković, A. Microparticles in Table Salt: Levels and Chemical Composition of the Smallest Dimensional Fraction. J. Mar. Sci. Eng. 2019, 7, 310. [CrossRef] 